\title{
REVIEW
}

\section{Bench-to-bedside review: Neonatal sepsis - redox processes in pathogenesis}

\author{
Ivan Spasojević ${ }^{*}$, Budimir Obradović ${ }^{2}$ and Snežana Spasić ${ }^{3}$
}

\begin{abstract}
The present review is aimed at elucidating the neonatal 'sepsis redox cycle' - the cascade of inflammatory and redox events involved in the pathogenesis of sepsis in neonates. While adult and neonatal sepses share some common features, there are some substantial differences: higher mortality rates occur in adult sepsis and worse long-term effects are evident in neonatal sepsis survivors. Such epidemiological data may be explained by the lower ability of IL6 and IL8 to activate NF-KB-regulated transcription in neonatal sepsis in comparison to TNF-a, which is involved in the mechanisms of adult sepsis. The activation of NF-kB in neonatal sepsis is further promoted by hydrogen peroxide and results in mitochondrial dysfunction and energy failure as septic neonates experience decreased $\mathrm{O}_{2}$ consumption as well as lower heat production and body temperature in comparison to healthy peers. In neonates, specific organs that are still under development are vulnerable to sepsis-provoked stress, which may lead to brain, lung, and heart injury, as well as vision and hearing impairments. In the light of the processes integrated here, it is clear that therapeutic approaches should also target specific steps in the neonatal 'sepsis redox cycle' in addition to the current therapeutic approach that is mainly focused on pathogen eradication.
\end{abstract}

\section{Introduction}

Sepsis is a devastating health problem taking millions of lives every year in neonatal ICUs (NICUs) all around the world $[1,2]$. The original hypothesis addressing the pathogenesis of sepsis that blamed aggressive immune activity for sepsis-related health problems and death was

\footnotetext{
*Correspondence: redoxsci@gmail.com

'Institute for Multidisciplinary Research, University of Belgrade, Kneza Višeslava 1, 11000 Belgrade, Serbia

Full list of author information is available at the end of the article
}

countered by new facts showing that sepsis is best explained by generally reversible mitochondrial and cellular dysfunction [3]. Taking into account that an activated immune system and dysfunctional mitochondria represent the two most potent sources of reactive molecular species and that many reports imply an important role of reactive oxygen and nitrogen species (ROS and RNS) in the pathogenesis of sepsis, we recently outlined the main redox events that are interconnected in a self-sustaining and self-promoting pathological process we term the 'sepsis redox cycle', which may result in the total loss of cellular and organ function [3]. This review is aimed at elucidating the 'sepsis redox cycle' in neonatal sepsis (the neonatal 'sepsis redox cycle'), and represents a logical extension of our previous review, which was based on the available data addressing sepsis in adults. A complete picture of neonatal sepsis and therapy potentials requires a thorough understanding of the developmental differences that separate the pathogenesis of adult and neonatal sepses. While adult and neonatal sepses share some common features, there are some substantial differences: higher incidence and mortality rates are observed for adult sepsis, while long-term effects are worse in neonatal sepsis survivors. Fortunately, in developed countries neonatal sepsis is rare (up to 9 cases per 1,000 newborns). An epidemiological study performed in the US has illustrated that the incidence of sepsis is agerelated, being highest in people over 65 years of age $(26.2 / 1,000)$, while in infants under 1 year of age it was $5.3 / 1,000$ [4]. In a population of sepsis patients admitted to ICUs and given both antibiotics and supportive care, neonatal sepsis is substantially less lethal (3 to $10 \%$ mortality rate in developed countries) [5-7] compared to sepsis in adults (mortality rate of around 35\%) according to the latest Surviving Sepsis Campaign report for 2010 [8]. This is somewhat surprising bearing in mind that neonatal sepsis has been a subject of significantly less research. We have undertaken a brief systematic search of PubMed (electronic database of the US National Library of Medicine) looking for articles that contain: (i) the term 'neonatal sepsis' or a combination of the words sepsis and neonatal, neonate, newborn or baby in the title/abstract section; and (ii) the word sepsis but 
neither of the previous terms in the same section. While the first search returned some 4,000 results, the second search returned around 50,000 papers, implying that comparatively less is known about neonatal sepsis. Therefore, significantly lower mortality rates in NICUs do not seem to be related to more developed therapeutic approaches and finely tuned care in comparison to ICUs, but to specific differences between neonatal and adult sepsis pathogenesis, making the former less lifethreatening. On the other hand, it seems that those who survive sepsis are more likely to develop different morbidities later in life if sepsis episode(s) took place during the first 4 weeks of life (neonatal period). It should be stressed that the long-term effects of sepsis have not been well documented, and there are not many studies on this issue. Nevertheless, two cohort studies on extremely low birth weight neonates reported a significantly increased incidence of a number of different morbidities at the age of 18 to 22 months in the population of neonatal sepsis survivors in comparison to age- and birth-weight-matched controls; these include respiratory distress syndrome, bronchopulmonary dysplasia, periventricular leukomalacia (PVL), severe intraventricular hemorrhage, cerebral palsy, and vision and hearing impairments $[9,10]$. A retrospective cohort study documented that only $28 \%$ of neonatal septic shock survivors were alive and were considered normal 18 months after the septic shock episode(s) [11]. In contrast, adult severe sepsis survivors generally show recovery of baseline or near-normal values of general health and most of the other 'quality of life' parameters (only) 6 months after the sepsis episode [12]. Although different neurocognitive impairments have been reported in adult sepsis survivors, a consistent finding across investigations is that no associations exist between the indicators of severity and the development of unfavourable neurocognitive outcomes in survivors of critical illness [13]. Adult sepsis studies examining morbidities other than these are not available, but there are data on outcomes in an acute respiratory distress syndrome cohort and in a general population of ICU survivors. These surveys showed that nearly all acute respiratory distress syndrome patients fully recover lung function within 1 year [14], while ICU patients that survived renal failure almost always experience a complete recovery of renal function [15]. Such disparity in long-term effects further points out that there are significant differences between the mechanisms of neonatal and adult sepsis. Therefore, to come to new conclusions and the mechanism of neonatal sepsis pathogenesis, we will compare neonatal and adult sepsis step-by-step, from initial events all the way down to cellular dysfunction, focusing on redox processes but not underestimating other components, such as immune system activity. It should be stressed here that data available on neonatal sepsis are rather limited, as illustrated by the number of published papers. This may represent the reason why some previous reviews addressing mechanisms of neonatal sepsis failed to resist the temptation to combine data from neonatal with those from adult sepsis studies. This is not the case with the present review, as we have carefully separated neonatal from adult sepsis, underlining the caveats in the state-of-the-art knowledge on the former.

\section{Redox mechanisms in neonatal sepsis Pathogen-provoked events in the plasma}

Sepsis is a process that is initiated by pathogens, followed by increased immune system activity that activates a redox cascade in the intracellular compartment, and ends in cell and organ dysfunction [3]. The fact that pathogens are the initiators of a process that is thereafter principally independent of their presence is substantiated by the fact that a large percentage of septic adults (10 to $40 \%[16,17])$ and neonates (over $50 \%$ in some studies $[18,19]$ ) show negative blood cultures at some points during the disease course. Inflammatory responses related to tachycardia, tachypnea, hyperthermia or hypothermia and leukocytosis most commonly triggered by infection could also be present following trauma, burn injury and various other pathogen-unrelated insults [20]. Finally, the fact that neonates are comparatively more susceptible to infections but less to sepsis than adults [21] implies that pathogens do not play a central role in sepsis development. However, pathogens do induce an innate immune system response, which represents the second step in sepsis pathogenesis.

There are several key developmental differences in the host response to infection that clearly delineate neonatal sepsis as a separate entity from adult sepsis. The most obvious dissimilarity lays in the activity of the innate immune system. In comparison to the innate immune system and inflammatory response in adults, the neonatal system under septic conditions has: (i) a lower capacity to generate ROS and RNS; (ii) a different cytokine profile; (iii) a low neutrophil pool and a reduced capacity for increasing progenitor cell proliferation; (iv) neutrophil granulocytes exhibiting quantitative and qualitative abnormalities; (v) and neutrophils showing reduced function and an impaired capacity for migration, chemotaxis, endothelial adherence, and phagocytosis [22-24]. The first two points are particularly important here and require further explanation.

Neutrophils, macrophages and endothelial cells represent the first line of defence against pathogens and for this purpose they are equipped with different ROS and RNS that provoke oxidative damage and kill the invaders [3]. However, some of the reactive species produced, such as hydrogen peroxide $\left(\mathrm{H}_{2} \mathrm{O}_{2}\right)$ and nitric oxide $\left({ }^{\circ} \mathrm{NO}\right)$ are 
Table 1. The capacity of neonatal versus adult immune system cells to generate reactive oxygen species

\begin{tabular}{|c|c|c|c|c|c|}
\hline \multirow[b]{2}{*}{ Cell type } & \multirow[b]{2}{*}{ Stimulus } & \multirow[b]{2}{*}{ Parameter } & \multicolumn{2}{|r|}{ Group } & \multirow[b]{2}{*}{ Reference } \\
\hline & & & Neonate & Adult & \\
\hline Bovine polymorphonuclear leukocytes & PMA & $\cdot \mathrm{O}_{2}^{-} / 10^{6}$ cells $/ 5$ minutes $(\mathrm{nmol})$ & $5.7 \pm 0.8$ & $9.6 \pm 2.1(P<0.01)$ & [93] \\
\hline Human neutrophils & fMPL & Relative production of $\mathrm{O}_{2}$ - per minute & $8.0 \pm 3.6$ & $10.6 \pm 2.1(P<0.05)$ & {$[94]^{a}$} \\
\hline Human neutrophils & PMA & Relative production of $\mathrm{O}_{2}$ - per minute & $15.3 \pm 6.8$ & $27.5 \pm 4.8(P<0.01)$ & {$[94]^{\mathrm{a}}$} \\
\hline Human granulocytes & fMPL & Maximal ROS production in arbitrary units & $24 \pm 6$ & $57 \pm 8(P<0.01)$ & [95] \\
\hline Human alveolar macrophages & PMA & Intracellular $\mathrm{O}_{2}$ - production $\left(\mathrm{pmol} / 3 \times 10^{5}\right.$ cells) & $26 \pm 6$ & $94 \pm 22(P<0.05)$ & {$[96]$} \\
\hline Human alveolar macrophages & Opsonized zymosan & Intracellular ${ }^{\circ} \mathrm{O}_{2}^{-}$production $\left(\mathrm{pmol} / 3 \times 10^{5}\right.$ cells) & $50 \pm 16$ & $164 \pm 22(P<0.05)$ & [96] \\
\hline Human mononuclear phagocytes & IFN- $\gamma$ & $\mathrm{O}_{2}^{-}$release (nmol/106 cells) & $20 \pm 4$ & $31 \pm 5(P<0.01)$ & [97] \\
\hline
\end{tabular}

aWe extracted and pooled the results provided in the manuscript and performed statistical analysis using Statistica 6.0 (StatSoft, Inc., Tulsa, OK, USA); statistical significance was determined by the means of non-parametric two-tailed Mann-Whitney test. fMPL, N-formyl-methionyl-leucyl-phenylalanin (degradation product of bacterial proteins); IFN, interferon; $\mathrm{O}_{2}$; superoxide; $\mathrm{PMA}$, phorbol 12-myristate 13-acetate; $\mathrm{ROS}$, reactive oxygen species.

capable of crossing the cellular membrane to enter the intracellular compartment, where they may initiate and participate in the 'sepsis redox cycle' [3]. While this is true for adult sepsis, data show that when challenged by pathogens or experimental inducers, the oxidative burst performed by the neonatal immune system is significantly less pronounced than in adult sepsis (Table 1). As a result of lower ROS-generating activity of the innate immune system, neonatal plasma generally does not show positive markers of oxidative stress, which is in strong contrast to the results obtained in adults [3]. For example, Cherian and colleagues [25] reported that there were no significant changes in the levels of ascorbate, glutathione (GSH), and oxidative stress biomarkers in the blood of neonates and babies with sepsis when compared to agematched controls. Another study showed merely a slight increase in the level of lipid peroxidation products in the serum of septic neonates in comparison to controls [26]. A transient increase of total hydroperoxide level was reported in the blood of septic newborn piglets, while biological antioxidant potential was even increased at some time points during the 6 hour monitoring period [27]. Hydrogen peroxide has a central place in initiation of the 'sepsis redox cycle', so lower prooxidative activity of the neonatal immune system may account for the low incidence of sepsis in neonates. It is noteworthy that one Cochrane study showed that the supplementation of vitamin $\mathrm{E}$, which is involved in free radical scavenging in the blood, significantly increases the risk of sepsis in neonates [28]. This may be attributed to vitamin Emediated suppression of the already weak oxidative activity of the neonatal immune system, resulting in decreased bactericidal capacity.

While many cytokines are present at similar levels in the blood of neonatal and adult septic patients, some show substantial differences. Table 2 lists results from a series of studies documenting notably higher production of IL6 and IL8 and generally lower production of TNF- $\alpha$ in neonatal sepsis. In addition, IL6 and IL8 are significantly increased in the serum of septic neonates in comparison to uninfected peers, and probably represent the best early diagnostic markers for neonatal sepsis among the components of the immune system [29,30]. For example, Küster and co-workers [31] showed that the level of IL6 in the neonatal plasma increases approximately ten-fold two days before clinical diagnosis of sepsis. Other groups showed levels of IL6 and IL8 increased in septic neonates by approximately 20 - and 8 -fold, respectively [32], and 200 and 15 times, respectively, in comparison to healthy controls [33]. It is important to note here that plasma concentrations reflect only a small portion of the IL8 blood pool (approximately 10\%; most of IL8 is cell associated) [34]. This is also likely to be the case for IL6. Altogether, these data imply that while TNF- $\alpha$ represents the central mediator of sepsis in adults [35], this role is played by IL6 and IL8 in the pathogenesis of neonatal sepsis.

\section{Intracellular redox changes in neonatal sepsis}

Pro-oxidative and pro-inflammatory events in the plasma may have a strong impact on the intracellular milieu. In adult sepsis, $\mathrm{H}_{2} \mathrm{O}_{2}$ and TNF- $\alpha$ activate NF- $\kappa B$, which has a special place in sepsis development [3]. Its activity is significantly higher in septic non-survivors in comparison to controls and survivors and may predict sepsis-related mortality [36,37]. In spite of different redox settings and cytokine profiles, NF- $\mathrm{kB}$ is also activated in neonatal sepsis. Several studies showed that the stimulation of different neonatal cell types by lipopolysaccharide (LPS) results in the activation of NF- $\mathrm{kB}$, which was similar to or even higher than in adult systems [38-42]. Kenzel and colleagues [43] showed using a model of neonatal sepsis and two different bacterial species that NF-kB-dependent expression increases several fold in the presence of pathogens, while an in vivo investigation on newborn septic rats showed that NF- $\mathrm{kB}$ was activated in the lungs, 
Table 2. Levels of IL6, IL8 and TNF- $a$ in neonatal versus adult sepsis

\begin{tabular}{|c|c|c|c|c|c|c|}
\hline \multirow[b]{2}{*}{ Sample } & \multirow[b]{2}{*}{ Stimulus } & \multirow[b]{2}{*}{ Cytokine } & \multicolumn{2}{|c|}{ Group } & \multirow{2}{*}{$\begin{array}{l}\text { Other cytokines } \\
\text { showing } \\
\text { no difference }\end{array}$} & \multirow[b]{2}{*}{ Reference } \\
\hline & & & Neonate & Adult & & \\
\hline Human blood & GBS & $\begin{array}{l}\text { IL6 (pg/ml) } \\
\text { IL8 } \\
\text { TNF-a }\end{array}$ & $\begin{array}{c}100 \pm 105 \\
3,355 \pm 1,762 \\
592 \pm 349\end{array}$ & $\begin{array}{c}14 \pm 13(P=0.003) \\
1,109 \pm 452(P=0.01) \\
481 \pm 261(\mathrm{NS})\end{array}$ & $\mathbb{I L}-1 \beta$ & [98] \\
\hline Human blood & E. coli & $\begin{array}{l}\text { IL6 (pg/ml) } \\
\text { IL8 } \\
\text { TNF-a }\end{array}$ & $\begin{array}{c}1,000 \pm 0 \\
7,120 \pm 751 \\
952 \pm 167\end{array}$ & $\begin{array}{c}783 \pm 84(P=0.02) \\
4,995 \pm 472(P=0.003) \\
908 \pm 62(N S)\end{array}$ & $\mathbb{I L}-1 \beta$ & [98] \\
\hline Human blood & HSV-1 & $\begin{array}{l}\text { IL6 (pg/ml) } \\
\text { IL8 (ng/ml) }\end{array}$ & $\begin{array}{c}3,920 \pm 3750 \\
32 \pm 38\end{array}$ & $\begin{array}{c}360 \pm 190(P=0.033) \\
6.5 \pm 1.7(P=0.066)\end{array}$ & - & {$[99]^{\mathrm{a}}$} \\
\hline Human mononuclear cells & $\begin{array}{l}11 \text { bacterial }^{\text {species }}{ }^{b}\end{array}$ & $\begin{array}{l}\text { IL6 (ng/ml) } \\
\text { TNF-a }\end{array}$ & $\begin{array}{c}104 \pm 36 \\
16 \pm 14\end{array}$ & $\begin{array}{c}59 \pm 20(P<0.01) \\
17 \pm 15(N S)\end{array}$ & $\begin{array}{l}\text { IL10 } \\
\text { IL12 }\end{array}$ & {$[100]^{\mathrm{a}}$} \\
\hline Human monocytes & LPS & TNF-a (pg/ml) & 610 & $2,230(P<0.05)$ & - & [101] \\
\hline Human monocytes & LPS & $\begin{array}{l}\text { IL6 (ng/ml) } \\
\text { TNF-a }\end{array}$ & $\begin{array}{l}3.7 \pm 1.1 \\
0.6 \pm 0.2\end{array}$ & $\begin{array}{c}1 \pm 0.3(P<0.05) \\
3.3 \pm 1.3(P<0.05)\end{array}$ & - & [102] \\
\hline Human blood & LPS & TNF-a (ng/ml) & $1.47 \pm 1.03$ & $3.89 \pm 1.94(P<0.05)$ & $\begin{array}{l}\text { IL2 } \\
\text { IL4 } \\
\text { IFN- }-\gamma\end{array}$ & {$[38]$} \\
\hline
\end{tabular}

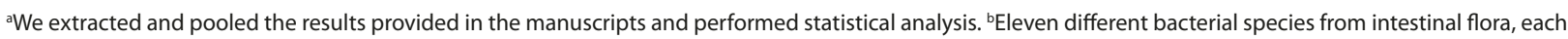
being studied separately. GBS, Group B streptococcus; HSV-1, herpes simplex virus type-1; IFN, interferon; NS, not significant.

liver, and spleen [44]. Recent studies shine a new light on NF- $\mathrm{kB}$ activation in neonatal sepsis. Manna and coworkers $[45,46]$ have shown that IL8 represents a NF-kB activator in different cell types. IL8 followed a time- and dose-dependent pattern of NF- $\mathrm{BB}$ activation that was similar to TNF- $\alpha$. However, IL8 is approximately two orders of magnitude less effective as an NF- $\mathrm{kB}$ activator in comparison to TNF- $\alpha$ - that is, similar levels of NF- $\mathrm{kB}$ regulated expression have been observed with IL8 at a concentration of $1 \mathrm{nM}$ as with TNF- $\alpha$ at $10 \mathrm{pM}[45,46]$. IL6 also represents an activator of NF-kB-regulated expression, and seems to be less efficient in comparison to TNF- $\alpha$ [47]. It is important to note here that IL6 binds to trans-membrane IL6 receptors, or forms a complex with soluble IL6 receptors, which associates with two molecules of the signal transducing protein gp130, thereby initiating intracellular signalling and NF-kB activation [48]. The lesser ability of IL6 and IL8 to activate NF- $\mathrm{kB}$-regulated transcription in comparison to TNF- $\alpha$ should be considered a possible reason for the lower incidence and mortality rates in neonatal sepsis. The levels of IL6 and IL8 increase during the first 12 to 24 hours of neonatal sepsis development, following which they generally decline in the blood to normal values characteristic of infection-free neonates [29]. This is in line with their role as initiators of a cascade of events that is independent of inflammatory processes thereafter.

NF $-\kappa B$ binds to DNA to enable the initiation of the transcription process of a number of genes, two of them encoding redox-active enzymes: inducible nitric oxide $(\cdot \mathrm{NO})$ synthase (iNOS) and cyclooxygenase-2 (COX-2; which generates superoxide $\left({ }^{\circ} \mathrm{O}_{2}^{-}\right)$as a by-product) [3].
Pertinent to the role of IL8 and IL6 in neonatal sepsis, it has been shown that the exposure of cells to these cytokines results in the expression/up-regulation of iNOS and COX-2 $[45,49]$. The increased expression and activity of iNOS and COX-2 have been documented in various tissues (brain, skeletal muscle, lung, and cardiac tissue) of rodent and porcine models of neonatal sepsis when initiated using Escherichia coli, GBS or LPS [41,5057]. The importance of the activation of iNOS expression in sepsis pathogenesis is substantiated by the findings of Mittal and co-workers [50], who showed that iNOS ${ }^{-/}$ newborn mice infected with $E$. coli display no disruption of the blood-brain barrier, a reduced inflammatory response and normal brain physiology. Generally, iNOS is absent in resting neonatal cells and is triggered by pathogens or cytokines, leading to the production of $\cdot \mathrm{NO}$ in the micromolar range [52]. This is much higher in comparison to the capacity of constitutively expressed endothelial nitric oxide synthase, which produces local 'NO concentrations in the nanomolar range [50]. Significantly increased $\mathrm{NO}$ production in septic neonates and neonatal sepsis models has been verified in a number of studies [50,58-60]. $\mathrm{NO}$ is known to provoke the inhibition of the electron transport chain in mitochondria in adult sepsis [61].

In addition to $\mathrm{COX}$-2-mediated $\mathrm{O}_{2}^{-}$production, this radical is produced in neonatal sepsis by NADPH oxidase and in mitochondria showing inhibited respiration. It has been shown that LPS treatment of rat neonatal cardiomyocytes leads to two-fold increased NADPH oxidase expression and $\mathrm{O}_{2}{ }^{-}$generation [40]. IL6 may promote $\mathrm{NADPH}$ oxidase $\cdot \mathrm{O}_{2}{ }^{-}$-producing activity [62], while 
Miyoshi and colleagues [63] have demonstrated using endothelial cells from umbilical vein that IL8 is directly involved in the activation of NADPH oxidase in sepsis. Investigations of mitochondrial function in neonatal sepsis are not very extensive, whereas data on ${ }^{\circ} \mathrm{O}_{2}$ - production in mitochondria under such settings are missing. Nevertheless, it has been shown using cytokine-treated cardiac myocytes and hepatocytes, both isolated from rat neonates, that ${ }^{\mathrm{NO}} \mathrm{O}$ inhibits the electron transport chain and normal mitochondrial functioning [64-66]. A study on hepatocytes from suckling rats with LPS-induced sepsis showed that intra-mitochondrial $\mathrm{O}_{2}$ consumption was decreased two-fold in comparison to controls, and that the mitochondria exhibited altered morphology, being swollen with indistinct cristae, disrupted membranes, and outer membrane fusion [67]. The dysfunction of mitochondria and energy failure in neonatal sepsis are also implicated by the fact that septic neonates experience rapidly decreased $\mathrm{O}_{2}$ consumption, as well as lower heat production and body temperature in comparison to healthy peers [68]. However, in contrast to adult sepsis, where ATP depletion has been well documented [3], the changes in ATP level have not been amply investigated in neonates. Only two studies have been performed on hepatocytes obtained from rat neonates very early in sepsis (2 hours after LPS injection), showing that there is no significant decrease in ATP levels $[67,69]$. This may be due to the ability of neonatal cells to compensate for mitochondrial dysfunction by extra-mitochondrial ATP production [67]. The compensation leads to excessive consumption of glucose and increased extra-mitochondrial $\mathrm{O}_{2}$ consumption, which have been documented in these studies $[67,69]$. Such production, however, yields only small amounts of ATP, which may maintain energy metabolism in balance for a short time, but with nonfunctioning mitochondria, glycolysis cannot prevent ATP depletion and cellular dysfunction in the long run. This remains to be substantiated by evidence on levels of ATP later in the course of neonatal sepsis development.

Superoxide reacts with $\mathrm{NO}$ to produce peroxynitrite (ONOO-), but there are no direct data showing the production and role of $\mathrm{ONOO}^{-}$in neonatal sepsis. However, the formation of $\mathrm{ONOO}^{-}$represents a simple chemical consequence of the co-existence of ${ }^{\circ} \mathrm{O}_{2}{ }^{-}$and 'NO [70], which most likely does not depend on cell age or type. Arstall and co-workers [71] showed that in neonatal rat ventricular myocytes exposed to cytokines, a sequence of events develops involving activation of iNOS and increased ${ }^{\prime} \mathrm{O}_{2}{ }^{-}$and $\mathrm{ONOO}^{-}$production. Mitochondria are specifically targeted by highly reactive products of ONOO' decomposition - ' $\mathrm{OH}$ and ${ }^{\cdot} \mathrm{NO}_{2}$ [3]. The first is notoriously reactive and provokes damage to membranes, proteins and DNA while ${ }^{\circ} \mathrm{NO}_{2}$ binds to proteins leading to increased susceptibility to protease-mediated degradation
[3]. Pertinent to this, Fukumoto and co-workers [66] have shown that ONOO- drastically affects the functioning of mitochondria isolated from the hearts of rat neonates.

The main consequence for ${ }^{\circ} \mathrm{O}_{2}$ - is to be dismutated to $\mathrm{H}_{2} \mathrm{O}_{2}$ in mitochondria by $\mathrm{Mn}$ superoxide dismutase (MnSOD) or in the cytoplasm by CuZnSOD. Hydrogen peroxide provokes further NF- $\mathrm{KB}$ activation [72], thus closing the redox loop. Pertinent to this, it has been reported that the expression of COX-2 in LPS-treated neonatal rat cardiomyocytes can be prevented by the inhibition of ${ }^{\circ} \mathrm{O}_{2}$ - production. Peng and colleagues [40] also showed that LPS-induced NF- $\kappa B$ activation is dependent on NADPH oxidase-mediated activity, which leads to increased levels of $\mathrm{H}_{2} \mathrm{O}_{2}$. These facts imply that extracellular stimuli (IL6, IL8, LPS) only push the cascade of events by activating NF- $\mathrm{kB}$-regulated expression, and the cascade then reaches maximum potential through $\mathrm{H}_{2} \mathrm{O}_{2}$-mediated activation, most likely representing a critical step in the development of neonatal sepsis. It is noteworthy that CuZnSOD over-expression is not beneficial in neonatal mouse brain cells showing mitochondrial dysfunction, implying the negative role of its product $-\mathrm{H}_{2} \mathrm{O}_{2}$. In contrast, over-expression of the $\mathrm{H}_{2} \mathrm{O}_{2}$ removing enzyme GSH peroxidase (GPx) was shown to be brain-protective [73]. In line with this, a Cochrane systematic review showed that the supplementation of selenium, which is necessary for GPx synthesis, was associated with a significant reduction in neonatal sepsis incidence [74]. It should be stressed that mitochondria base their defence against $\mathrm{H}_{2} \mathrm{O}_{2}$ on GPx activity [75]. Clearly, under conditions in which cellular respiration is obstructed, such as neonatal sepsis, the main problem comes from $\mathrm{H}_{2} \mathrm{O}_{2}$, which may leak from mitochondria or is produced by CuZnSOD in the cytoplasm. Hence, the positive effects of GPx in neonatal sepsis may be attributed to its ability to stop the redox loop.

Some other processes that have been described in adult sepsis still remain inconclusive in septic neonates. For example, the sequence of events involving ONOOmediated activation of poly(ADPribose) polymerase that leads to augmented ${ }^{\circ} \mathrm{O}_{2}$ production on mitochondrial complex I in adult sepsis [3] has not been studied in neonatal sepsis. In adult sepsis, ${ }^{-N O}$ is known to leak from cells into the blood, leading to methaemoglobin formation, hemolysis and increased iron availability, thus boosting pathogen proliferation [3]. Pertinent to this, there is only one obscure report showing higher methaemoglobin level in septic neonates in comparison to healthy controls [76].

Figure 1 amalgamates the key redox events in neonatal sepsis into a self-sustaining and self-promoting neonatal 'sepsis redox cycle'. It is important to note that we have presented only those steps in the pathogenesis of neonatal sepsis that have been substantially documented, 


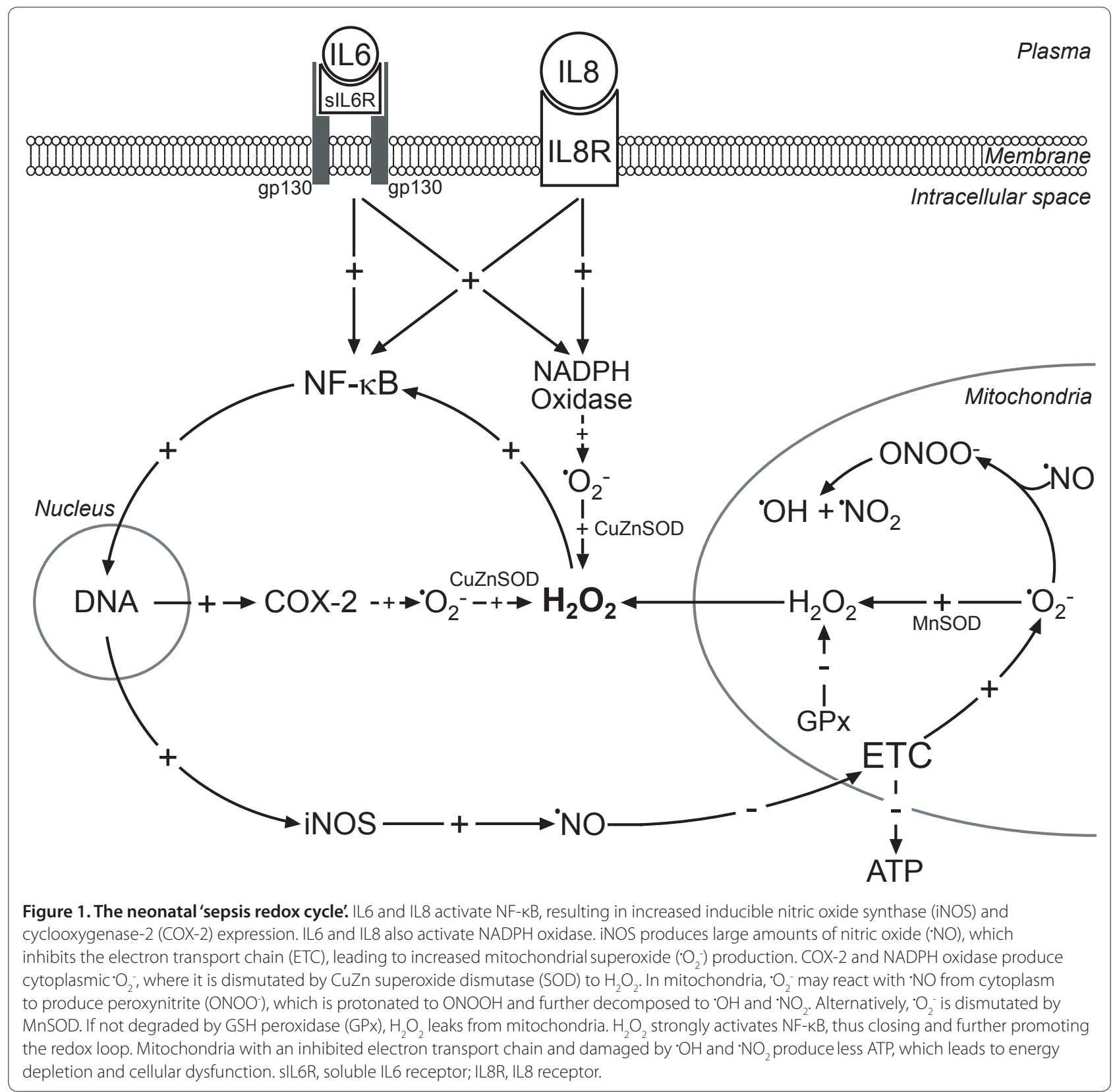

while some others remain to be further investigated. Instead of shutting down upon pathogen eradication or in the immune hypoactive phase, the neonatal 'sepsis redox cycle' continues to drain energy and prevents normal function to be re-established due to a positive feedback loop. The pathophysiological redox profile of one cell can spill over to surrounding tissue due to the ability of $\mathrm{H}_{2} \mathrm{O}_{2}$ and $\mathrm{NO}$ to cross membranes, thus leading to organ failure.

\section{The outcome}

While in adults sepsis-related cellular dysfunction is generally reversible [3], in neonates this seems to be far from the truth. In this fragile population, nervous, respiratory, and cardiovascular systems that are still developing are vulnerable to sepsis-provoked stress, which may lead to brain (PVL, intraventricular hemorrhage, cerebral palsy), lung (respiratory distress syndrome and bronchopulmonary dysplasia), and heart injury (patent ductus arteriosus), as well as vision and hearing impairments [10,77-79].

Together, a fall in ATP concentration and oxidative stress exerted on mitochondria and other compartments, both resulting from the neonatal 'sepsis redox cycle', may lead to mitochondrial permeability transition pore opening with eventual organelle swelling and cytochrome c release [80]. Once in the cytoplasm, cytochrome c can 
bind to apoptotic protease activating factor 1 (APAF-1) and thus activate caspase-9, which in turn activates caspases-3 and -7, culminating in apoptosis [81]. Proliferating cells in neonatal patients may be particularly susceptible to apoptosis, taking into account increased demands for energy in such cells. In addition, APAF-1, caspase- 3 and -9 , and the pro-apoptosis Bcl-2 family member Bim are present in higher concentrations in developing neonatal brain in comparison to adult brain tissue $[82,83]$. Bacteraemia is known to further promote caspase-3 gene expression in neonates [51], while the changes in mitochondrial morphology characteristic of apoptosis have been documented to develop in a neonatal sepsis model [67]. In contrast, immunohistochemical analysis has shown that apoptosis generally does not develop in adult sepsis [3].

Particularly vulnerable to oxidative injury and susceptible to apoptosis are oligodendrocyte progenitors and subplate neonatal neurons, which represent the major cellular targets in the pathogenesis of white matter injury/PVL in neonatal sepsis [84-86]. Hence, brainrelated morbidities in neonatal sepsis survivors may be explained by neonatal 'sepsis redox cycle'-provoked apoptosis in these specific cell types. Pertinent to this, the levels of IL6 and IL8 in the blood of septic neonates showed positive correlation with poor mental and psychomotor characteristics at the age of 2 [87]. The increased odds of developing visual impairments in neonatal sepsis survivors may be explained by the increased susceptibility of oligodendrocytes in the developing optic nerve to apoptosis [88], as well as by the fact that subplate neurons, which may be affected in sepsis, are required for normal visual cortical development [85]. Respiratory morbidities may be related to the fact that during early postnatal alveolar formation, the lung tissue undergoes a physiological remodelling involving apoptosis of distal lung cells [89]. For example, autopsy analysis of lungs of neonates who have died of fatal respiratory failure showed an elevated number of apoptotic cells in comparison to autopsy samples obtained from controls with no lung disease [90,91]. Finally, cardiovascular morbidities may be explained by a lower resistance of neonatal cardiomyocytes and cardiomyoblasts to apoptosis in comparison to adult cardiomyocytes. Activation of caspase- 9 and -3 , and cell death occur earlier and are more pronounced, while the levels of expression of the mitochondrial pro-apoptotic protein APAF-1 were significantly higher in neonatal compared to adult cells exposed to oxidative stress [92]. In summary, while the neonatal 'sepsis redox cycle' in most cells types may lead to reversible dysfunction, in others that are proliferating and sensitive to oxidative stress, it may initiate apoptosis, which seems to account for most morbidities found following a neonatal sepsis episode.

\section{Conclusion}

Although sharing many features with adult sepsis, neonatal sepsis exhibits its own hallmarks. The neonatal 'sepsis redox cycle' is initiated by IL6 and IL8, and further promoted by intracellular $\mathrm{H}_{2} \mathrm{O}_{2}$ production, while in adult sepsis TNF- $\alpha$ and extracellular $\mathrm{H}_{2} \mathrm{O}_{2}$ represent the initiators of the intracellular chain of redox events. The fact that the latter two are more effective NF- $\mathrm{kB}$ activators may explain why adult sepsis is more frequent and more deadly in comparison to neonatal sepsis. On the other hand, a higher susceptibility of developing cells to apoptosis may explain the more frequent and wider spectrum of morbidities found in neonatal sepsis survivors. Current strategies in neonatal sepsis treatment are focused on pathogen eradication by an early application of antibiotics, which is no surprise since neonatal sepsis represents one of the most rapidly fulminating clinical diseases in NICUs. However, the increased incidence of fungal and coagulase-negative staphylococci-provoked sepsis, potentially increased antibiotic resistance, and sporadic outburst of resistant strains in NICUs require an additive (early and safe) therapeutic approach that is beneficial independently of the pathogen that initiated the process. In light of the integrated processes described here, it is clear that such approaches should target specific steps in the neonatal 'sepsis redox cycle.'

\section{Abbreviations}

APAF-1, apoptotic protease activating factor 1; COX-2, cyclooxygenase-2; GSH, glutathione; GPx, GSH peroxidase; IL, interleukin; iNOS, inducible nitric oxide synthase; LPS, lipopolysaccharide; NF, nuclear factor; NICU, neonatal ICU; $N O$, nitric oxide; $P V L$, periventricular leukomalacia; RNS, reactive nitrogen species; ROS, reactive oxygen species; SOD, superoxide dismutase; TNF, tumour necrosis factor.

\section{Competing interests}

The authors declare that they have no competing interests.

\section{Acknowledgements}

Supported by the Ministry of Education and Science of the Republic of Serbia grant number O1173014'Molecular mechanisms of redox signaling in homeostasis, adaptation and pathology', and grant number 43004.

\section{Author details}

${ }^{1}$ Institute for Multidisciplinary Research, University of Belgrade, Kneza Višeslava 1, 11000 Belgrade, Serbia. ${ }^{2}$ Department of Paediatrics, Medical Centre 'Sveti Luka', Knez Mihajlova 51, 11300 Smederevo, Serbia. ${ }^{3}$ IChTM, University of Belgrade, Njegoševa 12, PO Box 473, 11001 Belgrade, Serbia.

\section{Published: 10 May 2012}

\section{References}

1. Thaver D, Zaidi AK: Burden of neonatal infections in developing countries: A review of evidence from community-based studies. Pediatr Infect Dis J 2009, 28:53-59.

2. Lawn JE, Cousens S, Zupan J: 4 million neonatal deaths: When? Where? Why? Lancet 2005, 365:891-900.

3. Andrades MÉ, Morina A, Spasić S, Spasojević I: Bench-to-bedside review: Sepsis - from the redox point of view. Crit Care 2011, 15:230.

4. Angus DC, Linde-Zwirble WT, Lidicker J, Clermont G, Carcillo J, Pinsky MR: Epidemiology of severe sepsis in the United States: analysis of incidence, outcome and associated costs of care. Crit Care Med 2001, 29:1303-1311. 
5. Baltimore RS: Neonatal sepsis: epidemiology and management. Paediatr Drugs 2003, 5:723-740

6. Bizzarro MJ, Raskind C, Baltimore RS, Gallagher PG: Seventy-five years of neonatal sepsis at Yale: 1928-2003. Pediatrics 2005, 116:595-602.

7. Wu JH, Chen CY, Tsao PN, Hsieh WS, Chou HC: Neonatal sepsis: a 6-year analysis in a neonatal care unit in Taiwan. Pediatr Neonatol 2009, 50:88-95.

8. Levy MM, Dellinger RP, Townsend SR, Linde-Zwirble WT, Marshall JC, Bion J, Schorr C, Artigas A, Ramsay G, Beale R, Parker MM, Gerlach H, Reinhart K, Silva E, Harvey M, Regan S, Angus DC: The Surviving Sepsis Campaign: results of an international guideline-based performance improvement program targeting severe sepsis. Intensive Care Med 2010, 36:222-231.

9. Benjamin DK Jr, Stoll BJ, Fanaroff AA, McDonald SA, Oh W, Higgins RD, Duara S, Poole K, Laptook A, Goldberg R: Neonatal candidiasis among extremely low birth weight infants: risk factors, mortality rates, and neurodevelopmental outcomes at 18 to 22 months. Pediatrics 2006, 117:84-92.

10. Stoll BJ, Hansen NI, Adams-Chapman I, Fanaroff AA, Hintz SR, Vohr B, Higgins RD: Neurodevelopmental and growth impairment among extremely lowbirth-weight infants with neonatal infection. JAMA 2004, 292:2357-2365.

11. Kermorvant-Duchemin E, Laborie S, Rabilloud M, Lapillonne A, Claris O: Outcome and prognostic factors in neonates with septic shock. Pediatr Crit Care Med 2008, 9:186-191.

12. Hofhuis JG, Spronk PE, van Stel HF, Schrijvers AJ, Rommes JH, Bakker J: The impact of severe sepsis on health-related quality of life: a long-term follow-up study. Anesth Analg 2008, 107:1957-1964.

13. Hopkins RO, Jackson JC: Long-term neurocognitive function after critical illness. Chest 2006, 130:869-878.

14. Herridge MS, Cheung AM, Tansey CM, Matte-Martyn A, Diaz-Granados N, Al-Saidi F, Cooper AB, Guest CB, Mazer CD, Mehta S, Stewart TE, Barr A, Cook $D$, Slutsky AS: One-year outcomes in survivors of the acute respiratory distress syndrome. N Engl J Med 2003, 348:683-693.

15. Morgera S, Kraft AK, Siebert G, Luft FC, Neumayer HH: Long-term outcomes in acute renal failure patients treated with continuous renal replacement therapies. Am J Kidney Dis 2002, 40:275-279.

16. Angus DC, Linde-Zwirble WT, Lidicker J, Clermont G, Carcillo J, Pinsky MR: Epidemiology of severe sepsis in the United States: analysis of incidence, outcome and associated costs of care. Crit Care Med 2001, 29:1303-1311.

17. Vincent JL, Sakr Y, Sprung CL, Ranieri VM, Reinhart K, Gerlach H, Moreno R, Carlet J, Le Gall JR, Payen D: Sepsis in European intensive care units: results of the SOAP study. Crit Care Med 2006, 34:344-335.

18. Sarkar S, Bhagat I, DeCristofaro JD, Wiswell TE, Spitzer AR: A study of the role of multiple site blood cultures in the evaluation of neonatal sepsis. J Perinatol 2006, 26:18-22.

19. Kayange N, Kamugisha E, Mwizamholya DL, Jeremiah S, Mshana SE: Predictors of positive blood culture and deaths among neonates with suspected neonatal sepsis in a tertiary hospital, Mwanza-Tanzania. BMC Pediatr 2010, 10:39.

20. Wynn J, Cornell TT, Wong HR, Shanley TP, Wheeler DS: The host response to sepsis and developmental impact. Pediatrics 2010, 125:1031-1041.

21. Posfay-Barbe KM, Zerr DM, Pittet D: Infection control in paediatrics. Lancet Infect Dis 2008, 8:19-31.

22. Tarnow-Mordi W, Isaacs D, Dutta S: Adjunctive immunologic interventions in neonatal sepsis. Clin Perinatol 2010, 37:481-499.

23. Edmond K, Zaidi A: New approaches to preventing, diagnosing, and treating neonatal sepsis. PLoS Med 2010, 7:e1000213.

24. Melvan JN, Bagby GJ, Welsh DA, Nelson S, Zhang P: Neonatal sepsis and neutrophil insufficiencies. Int Rev Immunol 2010, 29:315-348.

25. Cherian S, Jameson S, Rajarajeswari C, Helena V, Latha L, Rekha A, Nagamma T, Raju S, Kini PG, Rao A: Oxidative stress in sepsis in children. Indian J Med Res 2007, 125:143-148.

26. Batra S, Kumar R, Seema, Kapoor AK, Ray G: Alterations in antioxidant status during neonatal sepsis. Ann Trop Paediatr 2000, 20:27-33.

27. Kakita H, Hussein MH, Daoud GA, Kato T, Murai H, Sugiura T, Mizuno K, Yamada Y, Ito T, Fukuda S, Kato I, Suzuki S, Togari H: Total hydroperoxide and biological antioxidant potentials in a neonatal sepsis model. Pediatr Res 2006, 60:675-679

28. Brion LP, Bell EF, Raghuveer TS: Vitamin E supplementation for prevention of morbidity and mortality in preterm infants. Cochrane Database Syst Rev 2003, 3:CD003665.

29. Volante E, Moretti S, Pisani F, Bevilacqua G: Early diagnosis of bacterial infection in the neonate. J Matern Fetal Neonatal Med 2004, 16:13-16.
30. Ng PC, Lam HS: Biomarkers for late-onset neonatal sepsis: cytokines and beyond. Clin Perinatol 2010, 37:599-610.

31. Küster H, Weiss M, Willeitner AE, Detlefsen S, Jeremias I, Zbojan J, Geiger R, Lipowsky G, Simbruner G: Interleukin-1 receptor antagonist and interleukin- 6 for early diagnosis of neonatal sepsis 2 days before clinical manifestation. Lancet 1998, 352:1271-1277.

32. Nese Citak Kurt N, Aygun AD, Godekmerdan A, Kurt A, Dogan Y, Yilmaz E: Serum IL-1 $\beta$, IL-6, IL-8, and TNF- $a$ levels in early diagnosis and management of neonatal sepsis. Mediators Inflamm 2007, 2007:31397.

33. Krueger M, Nauck MS, Sang S, Hentschel R, Wieland H, Berner R: Cord blood levels of interleukin- 6 and interleukin-8 for the immediate diagnosis of early-onset infection in premature infants. Biol Neonate 2001, 80:118-123.

34. Orlikowsky TW, Neunhoeffer F, Goelz R, Eichner M, Henkel C, Zwirner M, Poets CF: Evaluation of IL-8-concentrations in plasma and lysed EDTA-blood in healthy neonates and those with suspected early onset bacterial infection. Pediatr Res 2004, 56:804-809.

35. Tang GJ, Huang SL, Yien HW, Chen WS, Chi CW, Wu CW, Lui WY, Chiu JH, Lee TY: Tumor necrosis factor gene polymorphism and septic shock in surgical infection. Crit Care Med 2000, 28:2733-2736

36. Arnalich F, Garcia-Palomero E, López J, Jiménez M, Madero R, Renart J Vázquez JJ, Montiel C: Predictive value of nuclear factor $\mathrm{kB}$ activity and plasma cytokine levels in patients with sepsis. Infect Immun 2000, 68:1942-1945

37. Böhrer H, Qiu F, Zimmermann T, Zhang Y, Jllmer T, Männel D, Böttiger BW, Stern DM, Waldherr R, Saeger HD, Ziegler R, Bierhaus A, Martin E, Nawroth PP: Role of NF-kB in the mortality of sepsis. J Clin Invest 1997, 100:972-985.

38. Koch L, Fritzsching B, Frommhold D, Poeschl J: Lipopolysaccharide-induced expression of Th1/Th2 cytokines in whole neonatal cord and adult blood: role of nuclear factor-kappa B and p38 MAPK. Neonatology 2011, 99:140-145.

39. Cao W, Li XQ Zhang XN, Hou Y, Zeng AG, Xie YH, Wang SW: Madecassoside suppresses LPS-induced TNF-alpha production in cardiomyocytes through inhibition of ERK, p38, and NF-kappaB activity. Int Immunopharmacol 2010, 10:723-729.

40. Peng T, Lu X, Feng Q: NADH oxidase signaling induces cyclooxygenase-2 expression during lipopolysaccharide stimulation in cardiomyocytes. FASEB J 2005, 19:293-295.

41. Hickson-Bick DL, Jones C, Buja LM: The response of neonatal rat ventricular myocytes to lipopolysaccharide-induced stress. Shock 2006, 25:546-552.

42. Jung HS, Yoon BH, Jun JK, Kim M, Kim YA, Kim CJ: Differential activation of mitogen activated protein kinases and nuclear factor-kappaB in lipopolysaccharide-treated term and preterm amnion cells. Virchows Arch 2005, 447:45-52

43. Kenzel S, Mancuso G, Malley R, Teti G, Golenbock DT, Henneke P: c-Jun kinase is a critical signaling molecule in a neonatal model of group $B$ streptococcal sepsis. J Immunol 2006, 176:3181-3188.

44. Pan F, Shi Y, Li HQ, Zhao JN, Tang SF, Yao ZK: Activation of nuclear factor kappa B in newborn rats sepsis. Zhonghua Er Ke Za Zhi 2003, 41:582-585.

45. Manna SK, Ramesh GT: Interleukin-8 induces nuclear transcription factorkappaB through a TRAF6-dependent pathway. J Biol Chem 2005, 280:7010-7021.

46. Manna SK, Babajan B, Raghavendra PB, Raviprakash N, Sureshkumar C Inhibiting TRAF2-mediated activation of NF-kappaB facilitates induction of AP-1. J Biol Chem 2010, 285:11617-11627.

47. Wang L, Walia B, Evans J, Gewirtz AT, Merlin D, Sitaraman SV: IL-6 induces NF-kappa B activation in the intestinal epithelia. J Immuno/ 2003, 171:3194-3201.

48. Scheller J, Chalaris A, Schmidt-Arras D, Rose-John S: The pro- and antiinflammatory properties of the cytokine interleukin-6. Biochim Biophys Acta 2011, 1813:878-888.

49. Tamariz L, Hare JM: Inflammatory cytokines in heart failure: roles in aetiology and utility as biomarkers. Eur Heart J 2010, 31:768-770

50. Mittal R, Gonzalez-Gomez I, Goth KA, Prasadarao NV: Inhibition of inducible nitric oxide controls pathogen load and brain damage by enhancing phagocytosis of Escherichia coli K1 in neonatal meningitis. Am J Pathol 2010, 176:1292-1305

51. Wang H, Wu YB, Du XH: Effect of dexamethasone on nitric oxide synthase and Caspase-3 gene expressions in endotoxemia in neonate rat brain. Biomed Environ Sci 2005, 18:181-186.

52. Orellana RA, Suryawan A, Kimball SR, Wu G, Nguyen HV, Jefferson LS, Davis TA: Insulin signaling in skeletal muscle and liver of neonatal pigs during 
endotoxemia. Pediatr Res 2008, 64:505-510.

53. Glibetic M, Samlalsingh-Parker J, Raykova V, Ofenstein J, Aranda JV: Group B Streptococci and inducible nitric oxide synthase: modulation by nuclear factor kappa B and ibuprofen. Semin Perinatol 2001, 25:65-69.

54. Nögel SC, Chada M, Schmidt AM, Bosselmann S, Kandler M, Schweer H, Watzer B, Schneider H, Gessner A, Rascher W: Parecoxib does not suppress thromboxane synthesis in newborn piglets with group B streptococcal sepsis. Prostaglandins Other Lipid Mediat 2009, 90:7-12.

55. Natarajan G, Glibetic M, Raykova V, Ofenstein JP, Thomas RL, Aranda JV: Nitric oxide and prostaglandin response to group B streptococcal infection in the lung. Ann Clin Lab Sci 2007, 37:170-176.

56. Kaftan HA, Clark PL, Norberg M, Garg U, Thibeault DW, Truog WE: Endogenous production of nitric oxide in endotoxemic piglets. Biol Neonate 2003, 83:42-48.

57. Hovsepian E, Penas F, Goren NB: 15 -deoxy- $\Delta^{12,14}$ prostaglandin GJ ${ }_{2}$ but not rosiglitazone regulates metalloproteinase 9, NOS-2, and cyclooxygenase 2 expression and functions by peroxisome proliferator-activated receptor Y-dependent and -independent mechanisms in cardiac cells. Shock 2010 34:60-67.

58. Ergenekon E, Gücüyener K, Erbaş D, Koç E, Ozturk G, Atalay Y: Urinary nitric oxide in newborns with infections. Biol Neonate 2000, 78:92-97.

59. Figueras-Aloy J, Gómez L, Rodríguez-Miquélez JM, Jordán Y, Salvia MD, Jiménez W, Carbonell-Estrany X: Plasma nitrite/nitrate and endothelin-1 concentrations in neonatal sepsis. Acta Paediatr 2003, 92:582-587.

60. Marom D, Yuhas Y, Sirota L, Livni G, Ashkenazi S: Nitric oxide levels in preterm and term infants and in premature infants with bacteremia. Biol Neonate 2004, 86:160-164.

61. Davies NA, Cooper CE, Stidwell R, Singer M: Inhibition of mitochondrial respiration during early stage sepsis. Adv Exp Med Bio/ 2003, 530:725-736.

62. Behrens MM, Ali SS, Dugan LL: Interleukin- 6 mediates the increase in NADPH-oxidase in the ketamine model of schizophrenia. J Neurosci 2008, 28:13957-13966

63. Miyoshi T, Yamashita K, Arai T, Yamamoto K, Mizugishi K, Uchiyama T: The role of endothelial interleukin-8/NADPH oxidase 1 axis in sepsis. Immunology 2010, 131:331-339.

64. Oddis CV, Finkel MS: Cytokine-stimulated nitric oxide production inhibits mitochondrial activity in cardiac myocytes. Biochem Biophys Res Commun 1995, 213:1002-1009.

65. Romeo C, Eaton S, Spitz L, Pierro A: Nitric oxide inhibits neonata hepatocyte oxidative metabolism. J Pediatr Surg 2000, 35:44-48.

66. Fukumoto K, Pierro A, Spitz L, Eaton S: Differential effects of neonatal endotoxemia on heart and kidney carnitine palmitoyl transferase I. J Pediatr Surg 2002, 37:723-726.

67. Markley MA, Pierro A, Eaton S: Hepatocyte mitochondrial metabolism is inhibited in neonatal rat endotoxaemia: effects of glutamine. Clin Sci (Lond) 2002, 102:337-344.

68. Garrett-Cox RG, Pierro A, Spitz L, Eaton S: Body temperature and heat production in suckling rat endotoxaemia: beneficial effects of glutamine. J Pediatr Surg 2003, 38:37-44.

69. Vejchapipat P, Eaton S, Fukumoto K, Parkes HG, Spitz L, Pierro A: Hepatic glutamine metabolism during endotoxemia in neonatal rats. Nutrition 2002, 18:293-297.

70. Hare JM: Nitroso-redox balance in the cardiovascular system. N Engl J Med 2004, 351:2112-2114.

71. Arstall MA, Sawyer DB, Fukazawa R, Kelly RA: Cytokine-mediated apoptosis in cardiac myocytes: the role of inducible nitric oxide synthase induction and peroxynitrite generation. Circ Res 1999, 85:829-840.

72. Barnes PJ: Nuclear factor-kB. Int J Biochem Cell Biol 1997, 29:867-870.

73. Sheldon RA, Christen S, Ferriero DM: Genetic and pharmacologic manipulation of oxidative stress after neonatal hypoxia-ischemia. Int J Dev Neurosci 2008, 26:87-92.

74. Darlow BA, Austin N: Selenium supplementation to prevent short-term morbidity in preterm neonates. Cochrane Database Syst Rev 2003, 4:CD003312.

75. Martin M, Macias M, Escames G, Leon J, Acuna-Castroviejo D: Melatonin but not vitamins $C$ and $E$ maintains glutathione homeostasis in tert-butyl hydroperoxide induced mitochondrial oxidative stress. FASEB J 2000, 14:1677-1679.

76. Sanodze N, Uberi N, Uberi E, Kulumbegov B: Parameters of oxidative metabolism in neonates suffering from sepsis and anemia. Georgian Med News 2006, 140:65-67.
77. Adams-Chapman I, Stoll BJ: Neonatal infection and long-term neurodevelopmental outcome in the preterm infant. Curr Opin Infect Dis 2006, 19:290-297

78. Wheater M, Rennie JM: Perinatal infection is an important risk factor for cerebral palsy in very-lowbirthweight infants. Dev Med Child Neurol 2000 42:364-367.

79. O'Shea TM: Cerebral palsy in very preterm infants: new epidemiological insights. Ment Retard Dev Disabil Res Rev 2002, 8:135-145.

80. Crouser ED: Mitochondrial dysfunction in septic shock and multiple organ dysfunction syndrome. Mitochondrion 2004, 4:729-741.

81. Kroemer G, Reed JC: Mitochondrial control of cell death. Nature Med 2000, 6:513-519

82. Stoka V, Turk V, Bredesen DE: Differential regulation of the intrinsic pathway of apoptosis in brain and liver during ageing. FEBS Lett 2006, 580:3739-3745.

83. Madden SD, Donovan M, Cotter TG: Key apoptosis regulating proteins are down-regulated during postnatal tissue development. Int J Dev Biol 2007, 51:415-424.

84. Back SA, Han BH, Luo NL, Chricton CA, Xanthoudakis S, Tam J, Arvin KL, Holtzman DM: Selective vulnerability of late oligodendrocyte progenitors to hypoxia-ischemia. J Neurosci 2002, 22:455-463.

85. McQuillen PS, Sheldon RA, Shatz CJ, Ferriero DM: Selective vulnerability of subplate neurons after early neonatal hypoxia-ischemia. J Neurosci 2003, 23:3308-3315.

86. Volpe JJ: Neurobiology of periventricular leukomalacia in the premature infant. Pediatr Res 2001, 50:553-562.

87. Silveira RC, Procianoy RS: High plasma cytokine levels, white matter injury and neurodevelopment of high risk preterm infants: assessment at two years. Early Hum Dev 2011, 87:433-437.

88. Barres BA, Hart IK, Coles HS, Burne JF, Voyvodic JT, Richardson WD, Raff MC: Cell death and control of cell survival in the oligodendrocyte lineage. Cell 1992, 70:31-46

89. Yi M, Masood A, Ziino A, Johnson BH, Belcastro R, Li J, Shek S, Kantores C, Jankov RP, Tanswell AK: Inhibition of apoptosis by $60 \%$ oxygen: a novel pathway contributing to lung injury in neonatal rats. Am J Physiol Lung Cell Mol Physiol 2011, 300:L319-L329.

90. Lukkarinen HP, Laine J, Kääpä PO: Lung epithelial cells undergo apoptosis in neonatal respiratory distress syndrome. Pediatr Res 2003, 53:254-259.

91. Hargitai B, Szabó V, Hajdú J, Harmath A, Pataki M, Farid P, Papp Z, Szende B: Apoptosis in various organs of preterm infants: histopathologic study of lung, kidney, liver, and brain of ventilated infants. Pediatr Res 2001 50:110-114.

92. Konorev EA, Vanamala S, Kalyanaraman B: Differences in doxorubicininduced apoptotic signaling in adult and immature cardiomyocytes. Free Radic Biol Med 2008, 45:1723-1728.

93. Clifford CB, Slauson DO, Neilsen NR, Suyemoto MM, Zwahlen RD, Schlafer DH: Ontogeny of inflammatory cell responsiveness: superoxide anion generation by phorbol ester-stimulated fetal, neonatal, and adult bovine neutrophils. Inflammation 1989, 13:221-231.

94. Komatsu H, Tsukimori K, Hata K, Satoh S, Nakano H: The characterization of superoxide production of human neonatal neutrophil. Early Hum Dev 2001 65:11-19.

95. Safronova VG, Matveeva NK, Mal'tseva VN, Bondar' OE, Van'ko IV, Sukhikh GT: Evaluation of the Role of FMLF chemotaxic peptide receptors in umbilical cord blood granulocytes from newborns at risk of infectious inflammatory diseases. Bull Exp Biol Med 2008, 145:452-456.

96. Delacourt C, d'Ortho MP, Macquin-Mavier I, Pezet S, Housset B, Lafuma C, Harf A: Oxidant-antioxidant balance in alveolar macrophages from newborn rats. Eur Respir J 1996, 9:2517-2524

97. Maródi L, Káposzta R, Campbell DE, Polin RA, Csongor J, Johnston RB Jr: Candidacidal mechanisms in the human neonate. Impaired IFN-gamma activation of macrophages in newborn infants. J Immunol 1994, 153:5643-5649.

98. Mohamed MA, Cunningham-Rundles S, Dean CR, Hammad TA, Nesin M: Levels of pro-inflammatory cytokines produced from cord blood in-vitro are pathogen dependent and increased in comparison to adult controls. Cytokine 2007, 39:171-177.

99. Kurt-Jones EA, Belko J, Yu C, Newburger PE, Wang J, Chan M, Knipe DM, Finberg RW: The role of Toll-like receptors in herpes simplex infection in neonates. J Infect Dis 2005, 191:746-748.

100. Karlsson H, Hessle C, Rudin A: Innate immune responses of human neonatal 
cells to bacteria from the normal gastrointestinal flora. Infect Immun 2002, 70:6688-6696.

101. Peters AMJ, Bertram P, Gahr M, Speer CP: Reduced secretion of interleukin-1 and tumor necrosis factor-a by neonatal monocytes. Biol Neonate 1993, 63:157-162.

102. Angelone DF, Wessels MR, Coughlin M, Suter EE, Valentini P, Kalish LA, Levy O: Innate immunity of the human newborn is polarized toward a high ratio of IL-6/TNF-alpha production in vitro and in vivo. Pediatr Res 2006, 60:205-209

doi: $10.1186 /$ cc 11183

Cite this article as: Spasojević I, et al:: Bench-to-bedside review: Neonata sepsis - redox processes in pathogenesis. Critical Care 2012, 16:221. 